\title{
Superior Occipital Convolution
}

National Cancer Institute

\section{Source}

National Cancer Institute. Superior Occipital Convolution. NCI Thesaurus. Code C33689.

A gyrus or ridge in the occipital lobe of the brain above the superior sulcus. 